\title{
Clastogenicity of a Fungicide, Ediphenphos (Hinosan) in the Bone Marrow Cells of Mice In Vivo
}

\author{
S. P. Bhunya and J. Behera \\ Laboratory of Genetic Toxicology, Post-Graduate Department of Zoology, \\ Utkal University, Vani Vihar, Bhubaneswar-751004, India
}

Received March 18, 1983

Pesticidal organophosphate compounds including many fungicides constitute an important group of environmental contaminants, and genotoxicity of a number of these chemicals has been studied on plants and animals (Siebert et al. 1970, Epstein and Legator 1971, Ahmed and Grant 1972, Kappas et al. 1974, Wild 1975, Manna and Bardhan 1977, Shirasu et al. 1976, Vasudev and Krishnamurthy 1980, Podstavkova et al. 1980, Shirasu et al. 1980, Quinto et al, 1981, Nehz et al. 1982 and Amer and Fahmy 1982). Ediphenphos, a widely used organophosphate systemic fungicide has been reported non-mutagenic in bacterial test system (Shirasu et al. 1976). Probably no work has been done on the cytogenetic effects of ediphenphos on mammalian system in vivo. The present investigation provides information regarding the cytogenetic effects of ediphenphos $\left(\operatorname{Hinosan}^{\mathrm{R}}\right)$ on the bone marrow cells of mice in vivo.

\section{Materials and methods}

Test animal: Bone marrow tissues of inbred mice (Swiss strain) of age group 10-12 week were used in the present investigation.

Test chemical: Technical form of ediphenphos $\left(\right.$ Hinosan $\left.^{\mathrm{R}}\right)$ (O-ethyl-S, S-diphenyl-dithiophosphate) was donated by Bayer India Limited. The structure of this compound is as follows. Solutions of different concentrations of ediphenphos were prepared in $10 \%$ ethanol for treatments (1 $\mathrm{cc} / 100 \mathrm{gm}$ b.w). Equal volume of $10 \%$ ethanol served as controls.

Dose: Three different doses like 50, 30 and $10 \mathrm{mg} / \mathrm{kg}$ b.w have been used.

Route: Highest dose $(50 \mathrm{mg} / \mathrm{kg}$ b.w) was administered through intraperitoneal and oral routes and bone marrow cells were fixed after $24 \mathrm{~h}$ exposure in order to test route specific cytogenetic injury. Other two lower doses were administered intraperitoneally and bone marrow<smiles>CCOP(=O)(Sc1ccccc1)Sc1ccccc1</smiles>

STRUCTURE OF HINOSAN cells were fixed after $24 \mathrm{~h}$ exposure in order to test dose dependent cytogenetic injury.

Duration of exposure: Highest dose $(50 \mathrm{mg} / \mathrm{kg} \mathrm{b.w})$ of the test compound 
was administered intraperitoneally and bone marrow cells were fixed after 6, 24 and $48 \mathrm{~h}$ exposures. Two lower doses (30 and $10 \mathrm{mg} / \mathrm{kg}$ b.w) were exposed for only $24 \mathrm{~h}$.

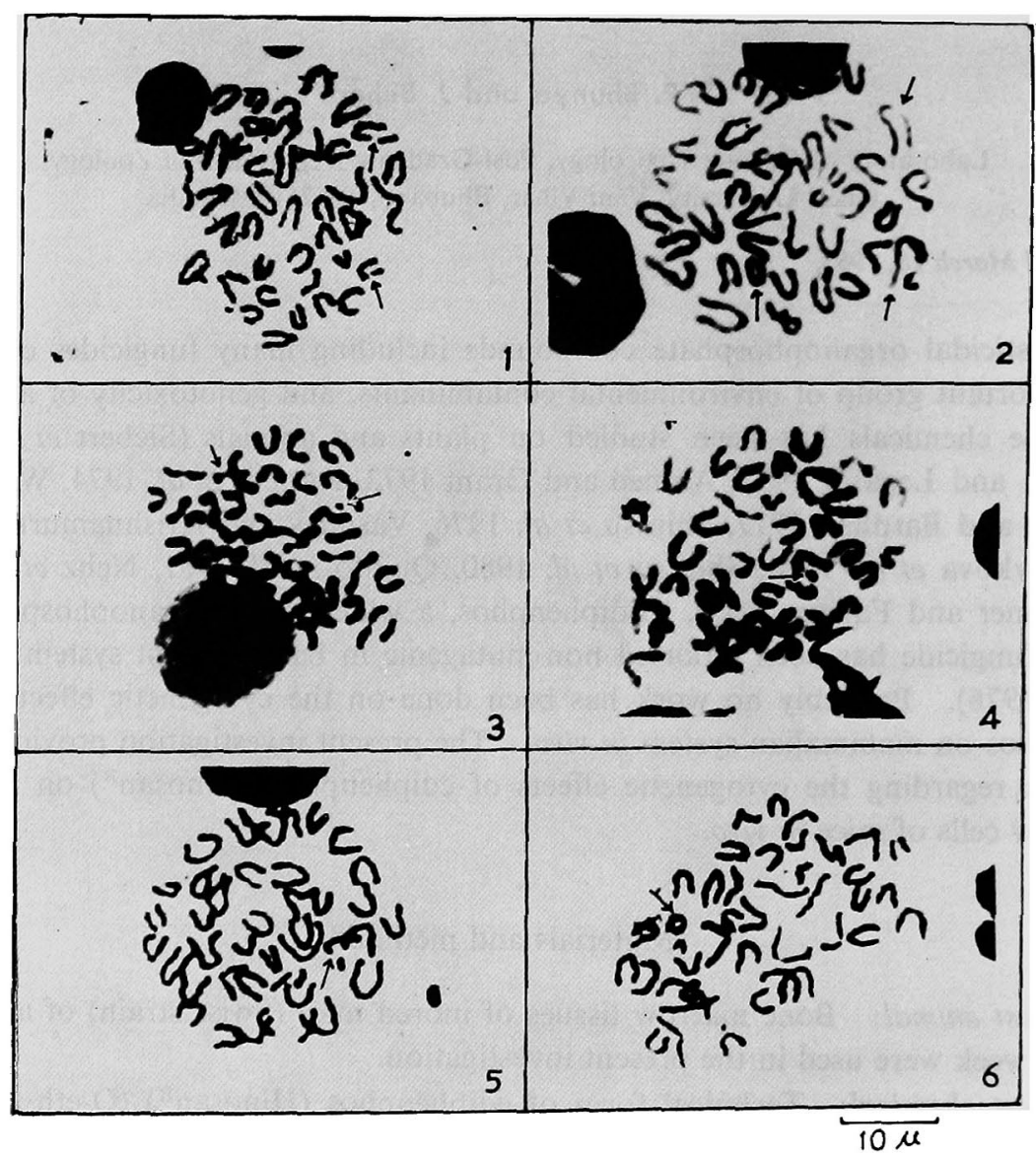

Figs. 1-6. 1, chromatid gap and break in proximal and middle regions respectively. 2, uneven chromatin stretching, chromatid break in proximal region and ring like structure. 3, chromatid gap and break. 4, chromatid gap in middle region. 5, chromatid break in middle region. 6 , ring chromosome.

Cytological slides from bone marrow tissue were prepared as per usual colchicine-citrate-acetic acid ethanol-air drying Giemsa schedule. Aberrations were scored from the slides under code.

From a single individual 60-75 cells were analysed. Chromosomes were divided into five groups as per Crippa (1964). Region and group wise occurrence of chromatid gaps and breaks were evaluated as per the procedure mentioned by Manna and Das (1973). An equality of the proportion test was used for statistical analysis of the result. The value is considered to be significant when $Z \geqslant 1.96$.

\section{Results}

In addition to physiological effects (corrosiveness, stickiness and uneven stre- 


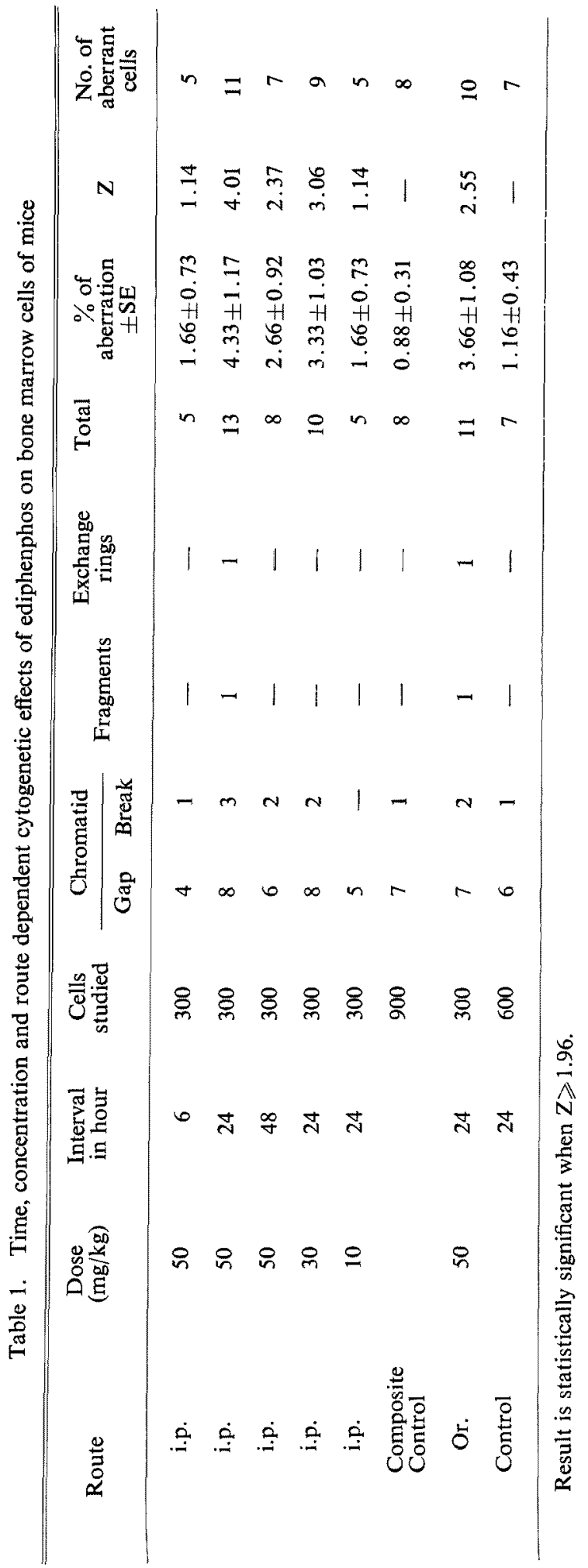




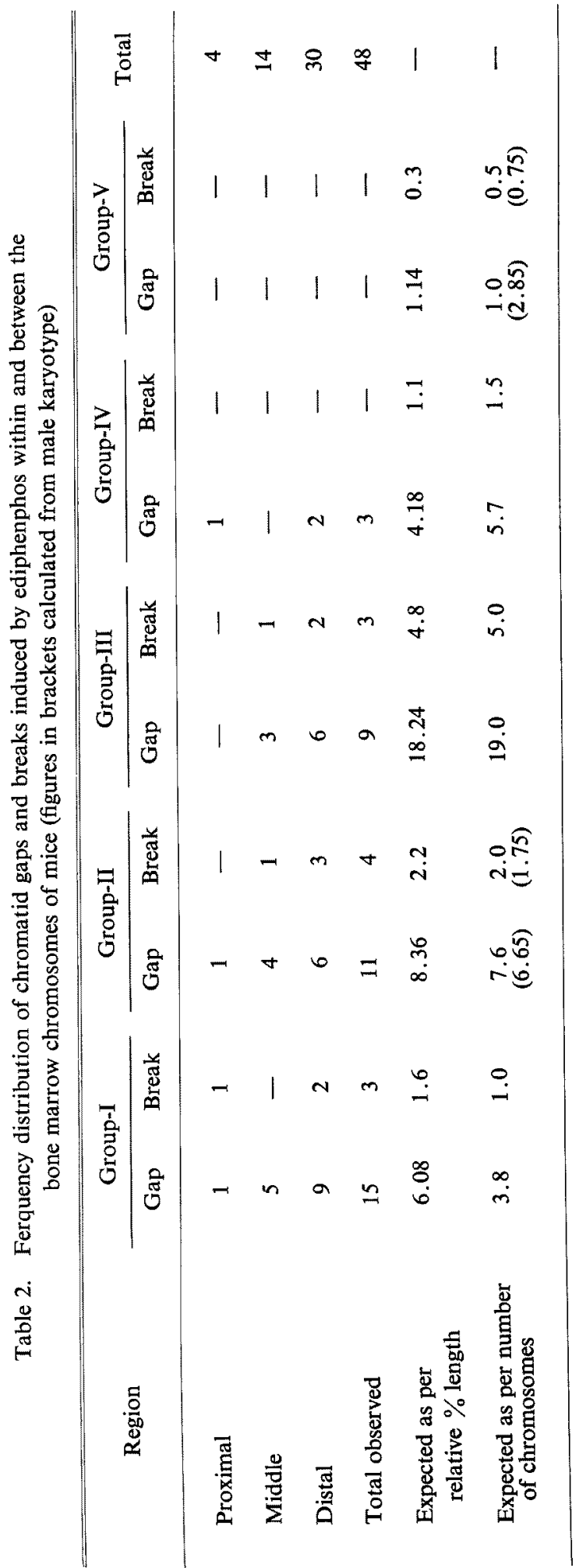


tching of chromatin material), chromatid type gaps, breaks, fragments and exchanges including rings were obtained following treatment with ediphenphos (Figs. 1-6). No chromosome type aberration was observed. Gaps out numbered breaks. Cells with multiple aberrations were rare. Details of route, dose and duration dependent cytogenetic effects of ediphenphos have been presented (Table 1). Induction of chromosomal injury was dependent on dose, duration and route of administration.

Larger chromosomes and regions away from centromere were more sensitive to damage (Table 2) induced by the fungicide. Most of the treated results deviated significantly $(Z \geqslant 1.96)$ from controls.

\section{Discussion}

Results indicated that ediphenphos is a mutagen in the present test system though it was found non-mutagenic in bacterial test by Shirasu et al. (1976) and this is probably due to in vivo transformation of the fungicide. However, decrease of aberration frequency in late hours and with lower doses indicates that probably due to non availability of the critical concentration of the genetically reactive metabolites at the target molecules (DNA and protein) and due to elimination of metabolites from the body with time. A critical concentration of reactive metabolites of chemical compound in the target tissue/cell is extremely important for production of any mutagenic events (see Matter 1976). After $24 \mathrm{~h}$ a small fraction of potential damage can be observed since major portions of potential damage are eliminated after one cell cycle time and this fact is also at per with the findings of Schmid (1973), Goetz et al. (1976) and Goetz and Novotna (1981). The compound is also more active cytogenetically in i.p. than in oral route administration which may be due to particular pharmacodynamic properties of the compound.

Though precise genetic significance of gaps is not clear but they are adequate indicators of genotoxic potential of chemicals (Nordenson et al. 1978). Non random occurrence of aberration points might be due to regional differences perhaps, in the base pairs as was proposed by Hsu and Somers (1961). More involvement of large chromosomes (group-I) and (group-II) and region away from centromere (mostly middle and distal regions) in the aberration process have also been known for other chemicals (Manna and Das 1973, Alam et al. 1974 and Behera and Bhunya 1980). The mechanism of action of ediphenphos metabolites at nucleic acid level is not known. However, organophosphorus pesticides are known for their alkylating properties (Wild 1975). So DNA akylation might be one of the reasons for the production of chromosomal aberrations by the chemical. Effects like corrosiveness, stickiness and stretching of chromatin material indicates that the fungicide may have acted upon the protein moiety of the chromosomes. Only chromatid type aberrations indicate that the chemical acted upon stages following $G_{1}$ stage of the cell cycle.

Cells with multibreaks were few since exchange figures were rare. However, ediphenphos has been found to be a clastogen in vivo in the present investigation. Hence careful handling and cautious use of this pesticide are suggested. 


\section{Summary}

Cytogenetic effects of a fungicide, ediphenphos have been studied on the bone marrow chromosomes of mice in vivo. Dose, route and duration of exposure largely influence the aberration frequency. The chemical has been found to be mutagenic in the present test system.

\section{Acknowledgements}

Authors are highly indebted to Dr. B. K. Behura, Mr. I. S. Rao, C. S. I. R. (Govt. of India) and Bayer India Limited for help.

\section{References}

Ahmed, M. and Grant, W. F. 1972. Cytological effects of the mercurial fungicide panogen-15 on Tradescantia and Vicia faba root tips. Mutation Res. 14: 391-396.

Alam, M. T., Corbell, M., Changnon, A. and Kasatiya, S. S. 1974. Chromosomal anomalies induced by the organic phosphate pesticide guthion in Chinese hamster cells. Chromosoma (Berl) 49: 77-86.

Amer, S. M. and Fahmy, M. A. 1982. Cytogenetic effects of pesticides. I. Induction of micronuclei in mouse bone marrow by the insecticide Dursban. Mutation Res. 101 : 247-255.

Behera, J. and Bhunya, S. P. 1980. In vivo effects of a commercial herbicide, amiben, on bone marrow and germ cells of mice. Caryologia 33: 527-535.

Crippa, M. 1964. The mouse karyotype in somatic cells cultured in vitro. Chromosoma 15: 301311.

Epstein, S. S. and Legator, M. S. 1971. The Mutagenicity of Pesticides, Concept and Evaluation. MIT Press (U.S.A).

Goetz, P., Sram, R. J., Kodytkova, I., Dohnalova, J., Dostalova, O and Bartova, J. 1976. Relationship between experimental results in mammals and man II. Cytogenetic analysis of bone marrow cells after treatment of cytembena and cyclophosphamide-cytembena combination. Mutation Res. 41: 143-152.

- and Novatna, B. 1981. Clastogenic effect of florafur II: Cytogenetic analysis of bone marrow in mice. Mutation Res. 88: 301-306.

Hsu, T. C. and Somers, C. E. 1961. Effect of 5-bromodeoxyuridine on mammalian chromosomes. Proc. Natl. Acad. Sci. (Washington) 47: 396-403.

Kappas, A., Georgopoolos, S. G. and Haste, A. G. 1974. On the genetic activity of benzimidazole thiphanate fungicides on diploid Aspergillus nidulans. Mutation Res. 26: 17-27.

Manna, G. K. and Das, R. K. 1973. Induction of chromosome aberrations by a sedative, barbital, in bone marrow cells of mice. Ind. J. Med. Res. 61: 1568-1573.

- and Bardhan, S. 1977. Chromosome aberrations in mice by antifungal antibiotic nystatin. Experientia 33: 306-307.

Matter, B. E. 1976. Problems of testing drugs for potential mutagenicity. Mutation Res. 38: 243-258.

Nehz, M., Fischer, G. W., Scheufler, H. and Selypes, A. 1982. Mutagenic effects of dimethoate and dimethyldimethoate in dominant lethality test and bone marrow cells of laboratory mouse. Mutation Res. 97: 207.

Nordenson, I., Beckman, G., Beckman, L. and Nordstrom, S. 1978. Occupational and environmental risks in and around smelters on Northern Sweden, II. Chromosomal aberrations in workers exposed to arsenic. Hereditas 88: 47-50.

Quinto, I., Martire, G., Vricella, G., Riccardi, F., Pertumo, A., Giulivo, R. and De Lorenzo, F. 1981. Screening of 24 pesticides by Salmonella/microsome assay: mutagenicity of bena- 
zolin, nitroxuron and paraoxon. Mutation Res. 85: 265.

Schmid, W. 1973. Chemical mutagen testing on in vivo somatic mammalian cells. Agents and Actions 3: 77-85.

Siebert, D., Zimmermann, F. K. and Lemperle, E. 1970. Genetic effects of fungicides. Mutation Res. 10: 533-543.

Shirasu, Y., Moriya, M., Kato, K., Furuhashi, A and Kada, T. 1976. Mutagenicity screening of pesticides in microbial system. Mutation Res. 40:19-30.

-, Huff, R. A., Wells, B. C. and Felkner, I. C. 1980. Mutagenicity and DNA damaging activity for several pesticides tested with Bacillus subtillis mutants. Mutation Res. 71: 169-179.

Wild, D. 1975. Mutagenicity studies on organophosphorus insecticides. Mutation Res. 32: 133150.

Vasudev, V. and Krishnamurthy, N. B. 1980. Non-mutagenicity of the fungicide dithane M-45 as inducer of recessive lethals after larval feeding in Drosophila melanogaster. Mutation Res. 77: 189-191. 